\title{
Local Consolidation Therapy
}

National Cancer Institute

\section{Source}

National Cancer Institute. Local Consolidation Therapy. NCI Thesaurus. Code C150254.

Any of various localized therapies designed to kill cancer cells left after initial treatment. 